\title{
Research on Implementation Plan of 5S Management in University Library
}

\author{
Xu Chuanjie \\ Library of Jianghan University, Jianghan University, Wuhan, 430056, P. R. China \\ xcjiejie@yeah.net
}

Keywords: University Library; 5S Management; Implementation Plan; Service Quality

\begin{abstract}
For the purpose of improving the service quality of university library, using enterprise 5S management experience, the specific implementation plan of 5S management is established from Seiri, Seiton, Seiso, Seiketsu and Shitsuke, according to the management work characteristics of university library. Furthermore, the specific measures of improving university service efficiency with 5S management are discussed. The practice of the 5S implementation plan enhanced the service quality of university library and increased reader satisfaction, which indicates the proposed scheme has good extension value.
\end{abstract}

\section{Introduction}

5S management (Seiri, Seiton, Seiso, Seiketsu and Shitsuke) originates in Japan, which means tidiness, orderliness, cleanliness, standardization and discipline [1]. The typical sample for 5S in international business is the automobile industry in Japan. With the wide application of 5S management, the enterprises lay a solid foundation for the production of world-class quality products of cars. In fact, the earlier manufacturing products in 20 century in Japan have inferior quality and low competitiveness in international market. After the Second World War, Japanese product quality is quickly upgraded because $5 \mathrm{~S}$ management is considered as the main method in enterprise management. The automotive products made in Japan even beat those in USA, the old cars producing country.

As the centre of information resources, university library is the important base of providing knowledge with students, teachers and social readers [2]. The principal purpose of university library is serving for society, and the key task is management and service. Therefore, we should spare no efforts to solve the problems in management. As the thoughts of $5 \mathrm{~S}$ management fit the requirement of daily work in university library very well, the implementation plan can be borrowed and studied in university library to improve working efficiency and service quality. In this paper, the implementation plan based on 5S management is researched to create a good library service work environment and a harmonious management atmosphere.

\section{The Functions of 5s Management in University Library}

In everyday work, the following phenomenon may be happened in university library: office supplies and personal items are placed at random, computer lines are not beamed, the bookshelves have not been timely ordered, the corners are full of dusts, and corridor lighting is not enough. All these may be little cases in offices [3]. However, from such small errors, readers may come to the conclusions that the overall service quality of the library is low, and the management is backward. At the same time, with everyone regards these things as natural habits, some negative emotions such as fatigue, lazy, or even grievances may be resulted in. According to Formal management schemes of 5S management, librarians could form positive habits of working behavior and attitude. Hence the purpose of motivating staff enthusiasm and improving the service for readers can be achieved. The relationships among 5S are shown in Figure 1, which are indispensable and interconnected. 


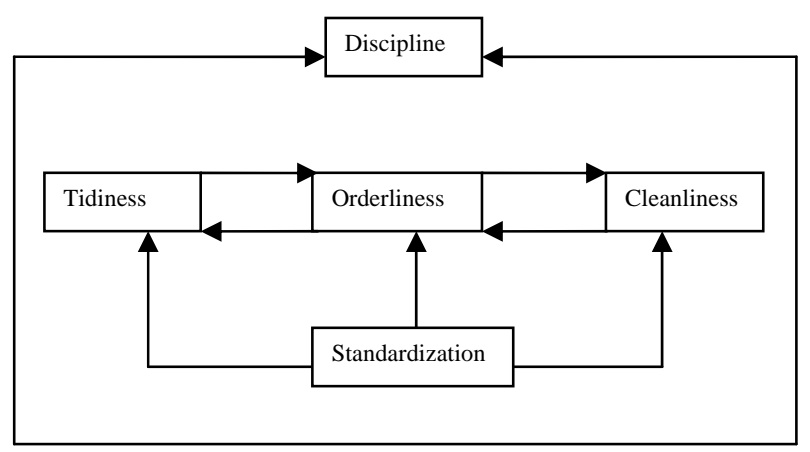

Figure 1. The relationships among 5S

\section{The Implementation plan of 5S Management in University Library}

Tidiness is verifying the necessary and unnecessary devices, and only necessary devices are allowed on the post, in order to increase work space and improve work efficiency. For example, in university library circulation department, tidiness includes two aspects: one is the equipment arrangement; the other is library resources arrangement. The equipment arrangement refers to the neglected book boards, the useless tables and chairs, the damaged computers and so on. If all these equipments are not arranged in time, it will cause the waste of space soon. Moreover, moving such useless equipments will lead to the waste of time and energy. Library resources arrangement means the classification of book resources according to their conditions, lending times, values, and preservation. To new books, the special book borrowing area can be set to facilitate readers. To old books, they should be eliminated in time if no one shows interests to them. To high borrowing rate books, they should be focused to open-shelf area to shorten the distance between readers and books. To low borrowing rate books which still have preserving values, they can be transferred to a second stack. From above discussion, the implementation plan of tidiness can be formulated as Table 1 .

Table 1. The implementation plan of tidiness

\begin{tabular}{ll}
\hline No & Content \\
\hline 1 & The unnecessary things are abandoned \\
\hline 2 & The ground and tables are messy \\
\hline 3 & Garbage box is full \\
\hline 4 & Office equipments are dusty \\
\hline 5 & The pass channels are separated \\
\hline 6 & The desks are arranged after work \\
\hline 7 & Having management rules on walls \\
\hline 8 & Books are classified according to the rules \\
\hline 9 & The power outlets are enough \\
\hline 10 & Line wiring is messy \\
\hline 12 & Line wiring is fixed \\
\hline 13 & Bookshelves are orderly arranged \\
\hline 14 & Power supplies are shut down after work \\
\hline 15 & Windows and doors are closed after work \\
\hline 16 & Office equipment is in normal state \\
\hline 17 & Bonsais have been watered \\
\hline
\end{tabular}

Orderliness means setting everything in proper place for quick retrieval and storage. Indeed, orderliness is researching how to improve efficiency. In university library, the main purpose of orderliness is placing books in proper place in terms of readers' demands, and creating a comfortable working environment to saving readers' time when they look for books. In a word, library orderliness is providing a reasonable layout of books for people. For example, setting schematic diagrams of collection at the entrance of reading rooms, marking the start-stop classification numbers and the corresponding categories, not stacking useless items, clearing each librarian's job position and area should be considered wholly. What's more, safety problem can not be overlooked. Escape route instructions should be clear, fire extinguisher should be placed reasonably, and safety education 
should be always carried out among readers. In this case, the implementation plan of orderliness can be designed as Table 2 .

Table 2. The implementation plan of orderliness

\begin{tabular}{|c|c|c|}
\hline No & Content & Result \\
\hline 1 & Having items whose purposes are unknown & \\
\hline 2 & Having items whose contents are unknown & \\
\hline 3 & Having useless items & \\
\hline 4 & Having misplacing items & \\
\hline 5 & ISBN is placed with false labels & \\
\hline 6 & Books are damaged & \\
\hline 7 & Labels are not clear & \\
\hline 8 & Book boards are in right position & \\
\hline 9 & Setting schematic diagrams of collection & \\
\hline 10 & Bookshelves layout is reasonable & \\
\hline 11 & Safety warning sign is legible & \\
\hline 12 & Fire extinguishers are placed reasonably & \\
\hline
\end{tabular}

Cleanliness means cleaning the workplace and everyone should be a janitor. After tidiness and orderliness, items needed should not only be handy, but also available and cleaning. The readers' satisfactions are closely related to the cleanness degree of library. Therefore, the maintenance of a beautiful and fresh library environment can lead to a comfortable feeling among readers and librarians. On the contrary, a dirty environment will not only influence the mood of readers and staff, but also make the equipments such as computers out of work easily. Consequently, librarians should clean the ground and desks and chairs in terms of responsibility positioning table. All devices should be arranged orderly and no much decorations should be located in desks. To make reading environment cleaning and comfortable, there should be no dust, no garbage, no dirt and no sundries in university library. The process of cleanliness is also the process of checking the devices and books during which the maintenance and management should be reinforced. From above discussion, the implementation plan of cleanliness can be formed as Table 3.

Table 3. The implementation plan of cleanliness

\begin{tabular}{|c|c|c|}
\hline $\begin{array}{l}\text { No } \\
\text {. }\end{array}$ & Content & Result \\
\hline 1 & Books are arranged on time & \\
\hline 2 & Bookshelves are arranged on time & \\
\hline 3 & Desks and drawers are arranged on time & \\
\hline 4 & Computers are put in good order & \\
\hline 5 & Book boards are put in good order & \\
\hline 6 & Private items are put in right place & \\
\hline 7 & Trolleys and racks are put in right place & \\
\hline 8 & Garbage is removed & \\
\hline 9 & Inlets and outlets are unblocked & \\
\hline 10 & Working environment is cleaned & \\
\hline
\end{tabular}

Standardization means standardizing the way of maintaining cleanliness. In university library, standardization should be done daily and could not be given up. Otherwise, the environments may turn back and all the efforts done may be useless. Therefore, standardization is doing tidiness, orderliness and cleanliness continuously. Based on the activities, standardization should become the customs of library. Meanwhile, readers should be educated to form good customs to be as the founder and maintainer of harmony environment in university library. A special supervision mechanism composed of leader of library, some librarians and readers can be established to look for problems, correct problems and solving problems in time. As a result, the implementation plan of standardization can be built as Table 4 .

Table 4. The implementation plan of standardization

\begin{tabular}{|c|c|}
\hline No & Responsibility \\
\hline 1 & Cleaning work environment continuously \\
\hline
\end{tabular}




\begin{tabular}{|c|c|c|}
\hline 2 & Dealing with unnecessary items & \multirow[t]{4}{*}{$\mathrm{n}$} \\
\hline 3 & Paying attention to appearance & \\
\hline 4 & Keeping air clean & \\
\hline 5 & Completing the arranged work & \\
\hline 1 & Setting working plans & \multirow{5}{*}{ Leader } \\
\hline 2 & Dividing the work area & \\
\hline 3 & Building detailed plan of departments & \\
\hline 4 & Supervision & \\
\hline 5 & Helping librarian solve difficulties & \\
\hline 1 & Keeping quiet in library & \multirow{4}{*}{ Reader } \\
\hline 2 & Keeping tidiness of books & \\
\hline 3 & Return books on time & \\
\hline 4 & Supervising the service work of library & \\
\hline
\end{tabular}

Discipline means practicing 5S daily, and making it a way of life. This also means 'commitment'. The purpose of discipline is forming good behavior and enterprising spirit through cultivating good habits, which is also the core of $5 \mathrm{~S}$ management. Without the quality improvement of librarian, all the $5 \mathrm{~S}$ activities can not be carried out, let along be persisted. The specific qualities of librarian include the following aspects: having a strong concept of time and complying with the time; abiding by the basic etiquette and behavioral criterions; obeying the library rules and regulations; dressing the uniforms and identities; participating library public activities actively; be polite and kind; respecting readers and serve for readers heartily. Therefore, the implementation plan of discipline can be drawn up as Table 5.

Table 5. The implementation plan of discipline

\begin{tabular}{ll}
\hline $\begin{array}{l}\text { No } \\
.\end{array}$ & Content \\
\hline 1 & At the meeting on time \\
\hline 2 & Not be absent or leave early \\
\hline 3 & Not doing private things on working time \\
\hline 4 & Attending library activities \\
\hline 5 & Be polite and kind to readers \\
\hline 6 & Be positive when working \\
\hline 7 & Having cooperation spirit \\
\hline 8 & Studying corresponding knowledge \\
\hline
\end{tabular}

\section{Conclusion}

University library has become the symbol of university development and its academic level. From the research of 5S management in enterprises, the specific 5S implementation plan of university library is established according to the daily working characteristics in this paper. The practice shows the service quality and the satisfaction degree of our library are improved, which indicate the proposed implementation plan is effective and efficient.

\section{References}

[1] Zhang Yonghong. Library Management Based on 5S Idea. Library and Information Service, 2005, (3): 85 88

[2] Han J.W., Kamber M. Data Mining: Concepts and Techniques. San Francisco: CA. Morgan Kaufmann, 2011

[3] Gray Marchionini. Research and development in digital libraries. New York: Marcel Dekker Inc, 1998

[4] Anwar, M.A. Professional development of librarians working in the university libraries of Pakistan. Library education in Pakistan: Past, present and future. Lahore: Punjab University Library Science Alumni Association. Vol. 9, pp. 65-73, 1991

[5] Sun Linyan. Human Factors Engineering. Beijing: Chineses science and technic press, 2005 